\title{
LOS MOTIVOS ESPAÑOLES EN LOS DRAMAS DEL "CICLO ESPAÑOL" DE ANDREJ HIENG
}

\section{Sobre el "ciclo español"}

El ciclo llamado español abarca cuatro obras: Burla sobre el griego (Burleska o Grku), Regreso de Cortés (Cortesova vrnitev), Hombre sordo en la frontera (Gluhi mož na meji) y Conquistador (Osvajalec). Hieng utiliza material histórico, en concreto la historia de España, como un medio para comunicar ideas, para presentar los destinos humanos, los problemas y las decisiones de la vida. Le interesa el hombre en relación con la historia, el transcurrir del tiempo, lo que trae a sus protagonistas conocimientos fundamentales de sí mismos y del mundo. Sus protagonistas son tragicómicos, como Don Quijote, porque el ideal de su vida, su orientación espiritual, se encuentra con una realidad histórica distinta, que no aceptan, quedándose así encerrados en su ideal. Esta lucha entre el ideal y la realidad los lleva a aflicciones psíquicas, a una mala e intranquila conciencia, a sensaciones de culpa, a la amargura y la duda sobre el sentido de sus acciones pasadas. Les persiguen el pasado y la historia. Las memorias les causan un mudo dolor en el presente y predican un futuro nada fácil. Al final esta lucha determina el destino de cada uno de los protagonistas: se dan cuenta y reconocen la realidad y con ello se abren dos soluciones posibles - o bien la aceptación y la serenidad o bien la mentira y la huida. El reconocimiento de la realidad ocurre en el presente, en el que se encuentran los personajes, pero está relacionado con las memorias, con el pasado que ocupa la mayor parte del drama, como ya hemos dicho, y que predica el futuro del protagonista: El Greco termina en un sosiego resignado, Goya en la rebelde y orgullosa resignación, don Francisco acepta el presente con lo que borra sus recuerdos de Méjico, de su pasado. En ello le ayuda la huida a la infancia, queriendo conectarla con el presente. Parece como si tratara de borrar a Méjico de su memoria, borrarlo como si fuera un fragmento de película que le gustaría quemar. En Conquistador estamos ante tres destinos: don Felipe está pasando los últimos días de aquel glorioso pasado de sangre cuando él creaba la historia. Después de la rebelión inútil termina en resignación y, en resignado sosiego, acepta la realidad; su hijo Baltasar concluye su lucha contra la realidad, muriendo (después de una loca venganza con la que intenta allanar la injusta corriente de la historia); y Margarita, la mujer india de don Felipe, es capaz de seguir adelante (como Goya) con un vitalismo y una alegría de vivir, es capaz da aguantar y solucionar la situación conflictiva.

El ciclo español es un ciclo de dramas psicológicos que se refieren a las memorias de los protagonistas, a su desengaño a reconocer, por una parte, que son importantes para la sociedad sólo por su gloria (El Greco y Goya), que son simplemente necesarios y que, por 
eso, se les exige negar su unicidad y estar de acuerdo con las autoridades gobernantes. Son dos artistas excepcionales que bajo la mortífera presión social o bien pierden sus ideales y se quedan paralizados en la impotencia creativa, o bien estallan en increíble, áspera y aguda crítica, llena de dolor por haber reconocido que todas las imágenes ideales no son sino polvo... Por otra parte don Francisco y don Felipe reconocen que hacian el mal en el nombre del bien y que ese mal les amenaza ahora con comerlos también a ellos mismos.

La impresión que el autor crea con sus protagonistas, con el ambiente entero y con la percepción del mundo en la obra (y que percibe también el lector) es mórbide, pesada, negra, sin salida, llena de miedo y de la muerte. Los protagonistas intentan conseguir en vano lo que no se puede: el tiempo corre, la historia igualmente, tan sólo quedan memorias e ilusiones perdidas y éstas son las que determinan el presente y el futuro. Cortés, solo y olvidado, va reconociendo su error: el de haber derramado demasiada sangre en su fanática fe y en su convicción de la extensión del Reino de Cristo en la Tierra, sembrando odio y preparando el camino a los colonizadores rapaces. Sus ilusiones se volatilizan igual que los bonitos sueños de El Greco, los sueños de la ideal y celeste Toledo, con la que tan convencido soñaba...

Veamos en primer lugar los dos dramas de la conquista - Conquistador y Regreso de Cortés - y sobre todo los motivos más destacados:

1. Una vez que el héroe ha conquistado un nuevo país su patria empieza a olvidarse de él y da todo el poder a la gente que no tiene las manos manchadas de sangre.

2. El total desagradecimiento, el sentimiento de estar rechazado y olvidado y de menospreciar los sacrificios y esfuerzos pasados, el sufrimiento etc. Todo esto provoca un dolor insoportable.

3. El preguntarse constantemente sobre el sentido de lo que habían hecho y el dudar de sus actos pasados. No les han traído como soñaban, entre otras cosas, la paz y el reino de Dios y tampoco el amor hacia Dios y hacia el hombre; sino la muerte y el odio. El mundo se derrumbó y empujó a los conquistadores al abismo espiritual, moral y físico.

El encuentro del amor y el odio.

4. La pérdida de la esperanza y de la fe en un mundo mejor y en el significado del porqué empeñarse en arreglar el mundo según su propia visión. Han dejado de creer en el sentido de la acción de Dios (no de su existencia sino de su presencia y justicia). Al principio Francisco cree todavía en la posibilidad de la reconquista, de la creación de un país nuevo cuando vuelva Cortés. Pero reconoce, después de hablar con él, que nada se puede cambiar, rehacer; que no hay solución, que está enterrada la esperanza. El pasado no ha tenido sentido; en el presente Francisco no sabe vivir, ¿cuál será su futuro?

Los protagonistas tienen dos caras: una invencible, fuerte y otra sin fe, llena de dudas... El cambio de los protagonistas se realiza de lo positivo a lo negativo: después de su hundimiento, después de darse cuenta de la realidad (la excepción aquí es Baltasar que llega de la pasividad a la acción rebelde, pero termina muerto), la fe pasa a la incredulidad, el amor al odio, la vida al vegetar, la dureza al llanto y a la humildad... 
De esta manera se nos plantean cuestiones filosóficas como el sentido de la transitoriedad de la existencia humana, cuestiones sobre las fuerzas mayores. (Dios, el tiempo, la historia) y la justificación de las matanzas en nombre de objetivos elevados, sobre el mentiroso y falso amor al prójimo etc. Y sobre todo: ¿Cómo soportar la imagen del mundo que es ciego, sordo, podrido, apestado, oscuro, pesimista, negativo y diabólico? ¿Cómo vencer el desengaño, la amargura y la resignación cuando uno se da cuenta que la realidad es distinta del ideal, de la esperanza y de los sueños?

\section{¿Dónde está el elemento español o latinoamericano en estos dos dramas?}

Sobre todo en el material histórico que sirve de escena: la conquista de Méjico, el carácter de Cortés, las batallas, las injusticias, los indios, el botín, las dudas, la situación política y social de España en los siglos de oro. Sobre todo debió de impresionarle al autor la conquista de Tenochtitlán, la capital mejicana, y el triunfo sobre los aztecas, los amos del Valle Mejicano. Hieng debió de estudiar bien las batallas porque de esos dramas emana la crueldad que se veía entonces en aquellas tierras. Si pudieramos detenernos más detalladamente encontraríamos en el texto un sin fin de referencias exactas, de datos históricos: los nombres de los lugares, la manera de luchar (la española y la india), los personajes históricos, como por ejemplo Moctezuma, y sus destinos, etc.

Se pueden comparar en cierto modo los dos dramas con el "Bautismo". (Krst) de Prešeren ${ }^{1}$, sobre todo con aquellos versos que describen la terrible lucha de Črtomir contra los paganos. Y hay otro paralelo entre "Bautismo" y los dramas mencionados: la paradoja cristiana de cómo relacionar la matanza, los hechos sangrientos con la fe cristiana, con el amor cristiano. No se puede contestar con una palabra pero podemos suponer que la religión era para ellos sólo la expresión de unas formas exteriores, de unos ritos, ceremonias y preceptos y que el espíritu cristiano había desaparecido hacía mucho.

El autor dice que describe a los personajes a través de la vida real, que no los inventa sino que tan sólo escoge de la multitud a los que llaman su atención. Estas palabras confirman lo que acabamos de decir sobre el material histórico.

Si a continuación examinamos el drama de El Greco - Burla sobre el griego -, tenemos que decir que la base histórica es la España del siglo XVI, el Renacimiento, la Inquisición, la vida de El Greco y su papel en el arte español de aquel entonces. También este texto nos ofrece una imagen de $\mathrm{El} \mathrm{Greco} \mathrm{en} \mathrm{la} \mathrm{que} \mathrm{se} \mathrm{reconoce} \mathrm{perfectamente} \mathrm{a} \mathrm{El}$ Greco histórico con su carácter, su arte y su compresión del arte, de la vida, de la religión... Los dos conflictos centrales que se nos presentan en el diálogo entre El Greco, su mujer Gerónima y el padre Cargano, muestran toda la problemática de la obra: la fe en la religiosa España y la búsqueda dei Dios personal. En una frase, la relación del individuo (que no es uno más de la masa) con la sociedad (y sus exigencias). La relación es doblemente

1 "Bautizo" (Krst) de France Prešeren (1800-1849): poema épico (1836) del poeta esloveno más destacado, que trata de los comienzos del cristianismo entre los paganos en el territorio esloveno de aquel entonces. 
conflictiva: o bien su relación como creyente con la iglesia o bien su relación como pintor con el arte.

Los problemas principales que se desarollan en el drama son:

1. La fe (que es fuerte al principio y que va disminuyendo poco a poco) en la religiosa España. El Greco idealiza demasiado esa España sin saber que la imagen "oficial" del país no coincide con la realidad por lo menos la idealizada visión de España, sobre todo de Toledo, que El Greco llevaba en sí mismo. Tampoco coincidían con la realidad las maravillosas visiones del reino de Dios que El Greco pintó toda su vida — por eso se preguntaba sobre el sentido de su obra pasada y su unicidad (igual que los protagonistas de los dos primeros dramas).

Podemos comparar a El Greco con $\mathrm{Trubar}^{2}$ que criticaba en sus predicaciones las procesiones, reuniones, peregrinajes, en las que veía un elemento pagano. Trubar se esforzaba a introducir la fe íntima, interior, en lugar de la imagen exterior y del vacío de la fe. Lo mismo se nota también en las reacciones de $\mathrm{El} \mathrm{Greco} \mathrm{ante} \mathrm{las} \mathrm{exigencias} \mathrm{de} \mathrm{las}$ "majestades eclesiásticas". Su dilema es obedecer las normas de la sociedad, aunque cristiana, o las normas de Dios; del corazón (entendido como la esencia de la persona) y de la conciencia que son necesariamente y siempre personales. Ante el mismo problema deberían detenerse los conquistadores antes de haber partido de España a América; pero ellos recibieron simplemente las normas sociales como si fuesen suyas propias y las cumplieron. Así se encontraron "post festum" ante un problema que era mucho más duro porque no dejaba ninguna elección: ¿Estaba bien lo que habian hecho?

2. La búsqueda del Dios personal se hace urgente cuando a El Greco se le destruye la fe en un Dios presentado eclesiástica y tradicionalmente. Al mismo tiempo se pierde también su fuerza artística que se basaba en la fe de la religiosa España, en la comunidad de la iglesia, que era pura ilusión. No sabe pintar más. Ahora quiere encontrar a Dios en la soledad de la reflexión porque ya no le queda otra cosa (ya que le abandona incluso su hijo). El regreso de su hijo es casi simbólico porque le impide a El Greco la continuación de la búsqueda. ¿Significa eso que admite la vieja realidad? El gobierno quiere "atraerle" por su gloria y prestigio (igual que a Goya, aunque con él no da resultado) y claro que a los gobernantes no les gusta su búsqueda, su individualismo. Pero El Greco hace lo que le parece necesario - sabe que el momento del encuentro enre él y Dios es la oración personal. Siente que la crisis de los cristianos, de la fe y de la iglesia es la crisis de la oración. Y lo dice. Sus palabras confirman las amenazas del padre Cargano, representante de la iglesia oficial. Cada día el hombre debe apostar por Dios o contra él; debe decidir, hasta la muerte - cuando ya es demasiado tarde para tomar decisiones porque entonces le queda tan sólo echar una ojeada por lo que ha vivido. El Greco lo sabe, por eso anhela un Dios personal y lo busca en las profundidades de su ser. No se conforma con lo superficial. ¿Significa su individualismo la negación de la iglesia como le reprocha el padre Cargano? Sea como

2 Primož Trubar (1508-1586): escritor protestante, iniciador de la literatura eslovena (Abecedarium, Cathecismus...). 
fuere, El Greco conoció la paradoja del cristianismo de aquel entonces: la fe es posible sólo si es posible apostar por ella, decidirse por ella o rechazarla libremente. Si una institución impone el cristianismo, lo destruye porque niega el mismo plan de Dios, que es la libre voluntad del hombre. El Greco habría dicho que no aceptaba el gobierno cristiano, que quería una iglesia cada vez más pobre y servidora, si se lo hubiéramos preguntado...

3. La familia juega un papel importante. Sirve de apoyo al protagonista a pesar de que al final incluso Gerónima se desespera porque no llega a comprender a su marido. A los dos les parece que viven un amor marchito y cansado, que están juntos por costumbre, que a lo mejor incluso se odian. Los sentimientos se están apagando, el amor verdadero no es sino memoria. Gerónima es portadora de la realidad y no de las ilusiones (igual que las mujeres de los dos dramas anteriores). En cuanto a la fe y a la iglesia ella es más "firme", puede que por no haberla idealizado o por no haberse preguntado tan profundamente sobre ella.

4. El monólogo final de El Greco, que en realidad es un diálogo con el sordomudo, nos revela su opinión (la de El Greco) sobre el sentido del trabajo y de la vida pasada. Está claro que este resumen de los pensamientos no habla exclusivamente de El Greco sino del hombre en general.

Antes de concluir, le debemos también algunas palabras a Goya - Hombre sordo en la frontera:

1. Al principio también él cree en la grande y religiosa España. Pero al reconocer la realidad se rebela contra ella con la sátira, con la ironía, con las imágenes grotescas que critican y quitan su máscara a la cara oficial del país. En éste drama se nota claramente cómo el poder oficial y también sus opositores (emigrantes) tratan de "conquistarle" - a Goya - no porque les interese Goya como tal sino su gloria y su prestigio. Pero Goya, solitario y razonable, no cede ante nadie. Le mueve la alegría de la vida, el vitalismo, que vence al conocimiento de lo pasajero, y el dualismo de estar pegado al pasado, de desear el futuro y de estar al mismo tiempo todo presente en el presente; lo que dificilmente se pueda decir de los protagonistas anteriores. Goya es un personaje soberano, capaz de vivir a su manera sin vanas esperanzas ni exageraciones.

2. Uno de los motivos principales es el contraste entre el amor y la muerte (como antes entre el amor y el odio) en su arte y en su vida. Ante el problema de la muerte Goya se queda en la mitad del camino. Siente un miedo espantoso ante la muerte que llena su alma, su vida y su arte. No sabemos cuál fue la verdadera causa de su locura pero intuímos que podría ser su "coco" - la muerte - a la que no supo responder y que empezó a pesarle infinitamente al final de su vida. Era un genio pero no suficientemente genial para encontrar una respuesta válida.

3. La profundidad del afecto humano enrte Isidro (el servidor del pintor) y Goya, que posibilita la irónica y despectiva relación al mismo tiempo que el respeto y la admiración, no es el último motivo del drama; podríamos encontrar y analizar muchos más como la 
relación entre la iglesia y el poder profano, la visión de Goya sobre el hombre y la mujer, etc.

\section{Conclusión}

Podemos hablar de lo típicamente español (o sea hispanoamericano) sólo en la elección del material histórico, de la base escenográfica: la conquista de Méjico, la vida de El Greco y de Goya, el ámbito cultural de la España de aquel entonces... Así que no se trata de dramas históricos o puramente españoles o latinoamericanos sino de dramas profundamente presentes, actuales, universales porque abren cuestiones sobre el sentido de la vida humana, de su transitoriedad; sobre la justificación de las matanzas en nombre de fines elevados; sobre el falso amor hacia el prójimo, sobre la muerte, la religión y la sociedad... El mundo está ciego, sordo, podrido, es un barranco del diablo; la resignación, el desengaño, la amargura, el pesimismo, la oscuridad, la ironía y la locura son abismos delante de los cuales se detienen los protagonistas de los dramas: ¿Dónde encotrarán las alas para atravesarlos?

\section{Povzetek}

\section{ŠPANSKI MOTIVI V HIENGOVI DRAMATIKI}

Če imenujemo Hiengov ciklus dram "španski", je poimenovanje upravičeno zaradi snovi, ki si jo je avtor izbral - osvajanje Mehike, bitke za zavzetje Tenochtitlana, Cortesova zvitost in odnos belcev do Indijancev, odnos Španije do osvajalcev... pa Španija v dobi razcveta (siglos de oro), El Grecovo življenje in doživljanje Toleda in umetnosti, Goyevo življenje, tedanje španske razmere... iz tega snovnega okvira vzame in predela motive, ki so splošno človeški - človek v odnosu do zgodovine in minevanja, stiske, ki jih povzročajo razhajanja med idealom in resničnostjo, občutki krivde, slabe vesti, nesmisla zaradi povzročanja zla $\mathrm{v}$ imenu dobrega, konflikti med enkratnim posameznikom in uniformirano družbo, nehvaležnost, dvom, izguba vere, upanja, opora družine... v tem okviru se dotika tudi problema krščanskega paradoksa pri osvajalcih (ubijati s Kristusovim imenom na ustnicah).

Drame so psihološke. Odgovor na vprašanja o smislu življenja in smrti, o sovraštvu in lažni ljubezni, o Bogu je slepota sveta. Okvir za dialog, snov, zgodovinsko ozadje dram pa je "špansko". 